\title{
Pyrimidine Deoxyribonucleotide Metabolism in Members of the Class Mollicutes
}

\author{
MARSHALL V. WILLIAMS ${ }^{1,2}$ AND J. DENNIS POLLACK ${ }^{1 *}$ \\ Department of Medical Microbiology and Immunology ${ }^{1}$ and Comprehensive Cancer Center, ${ }^{2}$ The Ohio State University, \\ Columbus, Ohio 43210
}

\begin{abstract}
Cell extracts from six Acholeplasma species, six Mycoplasma species, and Spiroplasma floricola $23-6^{\mathrm{T}}(\mathrm{T}=$ type strain) were examined for enzyme activities of pyrimidine deoxyribonucleotide metabolism. All of these organisms had thymidine kinase and thymidine phosphorylase activities, and all lacked deoxycytidine triphosphatase activity. The $\mathbf{1 3}$ members of the Mollicutes were separated into three groups by the presence or absence of the following four enzyme activities: (i) the adenosine triphosphate-insensitive deoxyuridine triphosphate-specific hydrolyzing deoxyuridine triphosphatase, (ii) a deoxyuridine monophosphate phosphatase, (iii) deoxycytidine deaminase, and (iv) deoxycytidine monophosphate deaminase. Five of the six Acholeplasma species (all Acholeplasma species except Acholeplasma florum $\mathbf{L 1}^{\mathrm{T}}$ ) had all four enzymatic activities. The six Mycoplasma species only had the deoxycytidine and deoxycytidine monophosphate deaminase activities. The only two plant isolates studied, $A$. florum $\mathrm{LI}^{\mathrm{T}}$ and $S$. floricola $23-6^{\mathrm{T}}$, lacked all four enzymatic activities.
\end{abstract}

The class Mollicutes contains two orders. The order Mycoplasmatales is composed of two families, the Mycoplasmataceae, which has two genera (Mycoplasma and Ureaplasma), and the Spiroplasmataceae, which has one genus (Spiroplasma) (4). The second order, Acholeplasmatales, contains one family, the Acholeplasmataceae, with one genus, Acholeplasma (5). A number of biochemical, nutritional, and morphological characteristics have been used to distinguish these genera and families. They include sterol requirement for growth, genome sizes, ability to hydrolyze urea, localization of reduced nicotinamide adenine dinucleotide oxidase, and presence of helical forms during growth $(4,5)$. However, no one has distinguished genera or families of the Mollicutes by the presence or absence of enzymes involved in pyrimidine deoxyribonucleotide metabolism.

Recently, we characterized the adenosine triphosphate (ATP)-insensitive highly specific deoxyuridine triphosphate (dUTP)-hydrolyzing deoxyuridine triphosphate nucleotidohydrolase (dUTPase; EC 3.6.1.23) from Acholeplasma laidlawii B-PG9 (17). In the present study, we examined five other Acholeplasma species, six Mycoplasma species, and one Spiroplasma species for dUTPase and other enzyme activities involved in pyrimidine deoxyribonucleotide metabolism. Our data suggest that it may be possible, with one exception, to distinguish these genera based upon the presence or absence of the ATP-insensitive dUTP-specific dUTPase (17), deoxyuridine monophosphate (dUMP) phosphatase, deoxycytidine (dC) deaminase, and deoxycytidine monophosphate (dCMP) deaminase activities in cell extracts.

\section{MATERIALS AND METHODS}

Chemicals. Nonradioactive nucleotides were purchased from Sigma Chemical Co., St. Louis, Mo. $\left[5-{ }^{3} \mathrm{H}\right] \mathrm{dUTP}(11$ $\mathrm{Ci} / \mathrm{mmol})$ and $\left[5-{ }^{3} \mathrm{H}\right] \mathrm{dCMP}(22 \mathrm{Ci} / \mathrm{mmol})$ were purchased from Moravek Biochemicals, Inc., Brea, Calif.; [5- $\left.{ }^{3} \mathrm{H}\right] \mathrm{dUMP}$ $(10 \mathrm{Ci} / \mathrm{mmol}),\left[5-{ }^{3} \mathrm{H}\right]$ deoxycytidine triphosphate (dCTP) $(21$ $\mathrm{Ci} / \mathrm{mmol}),\left[5-{ }^{3} \mathrm{H}\right] \mathrm{ATP}(29 \mathrm{Ci} / \mathrm{mmol})$, and $\left[2-{ }^{14} \mathrm{C}\right]$ thymidine

\footnotetext{
* Corresponding author.
}

(56.6 Ci/mmol) were purchased from Amersham Corp., Arlington Heights, Ill. Polyethyleneimine-cellulose thinlayer chromatography plates were purchased from Analtech, Newark, Del.

Organisms. Acholeplasma florum $\mathrm{L1}^{\mathrm{T}}$ ( $\mathrm{T}=$ type strain) and Spiroplasma floricola $23-6^{\mathrm{T}}$ were obtained from J. Tully, National Institute of Allergy and Infectious Diseases, Bethesda, Md. Acholeplasma axanthum S743 ${ }^{\mathrm{T}}$, Acholeplasma granularum BTS-39 ${ }^{\mathrm{T}}$, Acholeplasma hippikon $\mathrm{C1}^{\mathrm{T}}$, A. laidlawii B-PG9, Acholeplasma morum S2, Mycoplasma arginini $\mathrm{G}^{230^{\mathrm{T}}}$, Mycoplasma arthritidis 07, Mycoplasma gallisepticum S6, Mycoplasma hominis ATCC 14027, Mycoplasma pneumoniae $\mathrm{FH}^{\mathrm{T}}$, Mycoplasma pulmonis ATCC 19612 , and $M$. pulmonis JB were obtained from our stock collection.

Media and growth conditions. All Acholeplasma, Mycoplasma, and Spiroplasma species were grown in our modification of Edward medium (2). For growth of acholeplasmas, the medium was supplemented with $2 \%$ (vol/vol) heat-inactivated $\left(56^{\circ} \mathrm{C}, 1 \mathrm{~h}\right.$ ) horse serum (control lots 268095 and 200011 H; K. C. Biologicals, Lenexa, Kans.); for growth of mycoplasmas and spiroplasmas the medium was supplemented with this serum at a concentration of $4 \%$ ( $\mathrm{vol} / \mathrm{vol})$. For growth of $M$. arginini and $M$. hominis, Larginine hydrochloride (Calbiochem-Behring, La Jolla, Calif.) at a final concentration of $0.1 \%(\mathrm{wt} / \mathrm{vol})$ was added to media. All incubations were at $37^{\circ} \mathrm{C}$. Temperatureequilibrated media were inoculated with 1- to 4-day cultures (1 to $15 \%$, vol/vol).

Preparation of cell extracts. Cells were harvested in mid$\log$ growth (18 to $72 \mathrm{~h}$ ), washed, hypotonically lysed, and centrifugally fractionated, as described previously for enzyme location studies $(13,14)$. Acholeplasmal extracts were not subjected to further disruptive procedures, but all spiroplasmal and mycoplasmal preparations were also exposed to $65 \mathrm{~W}$ of sonic oscillation with a model 350 Branson Sonifier (Heat Systems Co., New York, N.Y.) for three 5-s bursts while they were in a wet ice bath. Crude cell lysates were used without further preparation for the assay of thymidine kinase activity. Washed membrane and cytoplasmic fractions were prepared by differential centrifugation (14) and were used for all other enzyme assays. Before 
TABLE 1. dUTP-hydrolyzing activities in cytoplasmic fractions of members of the Mollicutes ${ }^{a}$

\begin{tabular}{|c|c|c|}
\hline \multirow{2}{*}{ Organism } & \multicolumn{2}{|c|}{ Enzyme activity } \\
\hline & Without ATP & With ATP \\
\hline A. axanthum $\mathrm{S} 743^{\mathrm{T}}$ & $8.8 \pm 2.1(3)^{b}$ & $7.6 \pm 1.4(3)$ \\
\hline A. granularum BTS-39 & $7.3 \pm 0.5(3)$ & $6.2 \pm 0.8(3)$ \\
\hline A. hippikon $\mathrm{Cl}^{\mathrm{T}}$ & $7.6(1)$ & $8.3(1)$ \\
\hline A. laidlawii B-PG9 & $10.3 \pm 3.1(5)$ & $9.6 \pm 2.3(7)$ \\
\hline A. morum $\mathrm{S} 2$ & $6.8 \pm 1.2(3)$ & $7.1 \pm 0.6(3)$ \\
\hline A. florum $\mathrm{L1}^{\mathrm{T}}$ & $19.7 \pm 2.5(3)$ & $<0.001(3)^{c}$ \\
\hline S. floricola $23-6^{\mathrm{T}}$ & $2.1 \pm 0.8$ & $<0.001(3)$ \\
\hline$M$. arginini $\mathrm{G} 230^{\mathrm{T}}$ & $3.4 \pm 0.4(3)$ & $<0.001(3)$ \\
\hline M. gallisepticum S6 & $5.2 \pm 0.8(3)$ & $<0.001(3)$ \\
\hline M. hominis ATCC 14027 & $0.4 \pm 0.2(3)$ & $<0.001(3)$ \\
\hline M. arthritidis 07 & $<0.001(2)$ & $\mathrm{ND}^{d}$ \\
\hline M. pneumoniae $\mathrm{FH}^{\mathrm{T}}$ & $<0.001(2)$ & ND \\
\hline M. pulmonis ATCC 19612 & $<0.001(2)$ & ND \\
\hline M. pulmonis JB & $<0.001(2)$ & ND \\
\hline
\end{tabular}

${ }^{a}$ Reactions were performed as described previously (18) but using dUTP as the substrate, with or without ATP. The concentration of ATP added as a reaction competitor was $5 \mathrm{mM}$.

${ }^{b}$ Enzyme activity is expressed as nanomoles of dUMP formed per minute per milligram of protein (mean \pm standard deviation). The numbers in parentheses are the numbers of different batches of cells examined.

$c$ The minimum detectable amount was $0.001 \mathrm{nmol}$ of dUMP formed per min per $\mathrm{mg}$ of protein.

${ }^{d} \mathrm{ND}$, Not done.

assaying, washed membranes were suspended in TMG buffer [10 $\mathrm{mM}$ tris(hydroxymethyl)aminomethane hydrochloride (pH 7.5), $2 \mathrm{mM}$ 2-mercaptoethanol, $1 \mathrm{mM} \mathrm{MgCl}_{2}$, $20 \%$ (vol/vol) glycerol].

Enzyme assays. All of the procedures used for measuring enzymatic activities have been described previously (18). Assays for dUTPase and deoxycytidine triphosphatase (dCTPase) activities were performed in the presence and absence of competing ATP ( $5 \mathrm{mM})$. By using these methods, we could distinguish between dUTPase and dCTPase activities (which are both ATP insensitive and specific only for dUTP and dCTP, respectively) (17) and nonspecific dUTPand dCTP-hydrolyzing activities (which are both inhibited by ATP). dUMP phosphatase activity was assayed in the presence and absence of competing adenosine monophosphate $(4 \mathrm{mM})$. dUMP phosphatase activity is defined as adenosine monophosphate-insensitive hydrolysis of dUMP. To determine adenosine triphosphatase activity $(7,16)$, cytoplasmic and membrane fractions were tested for ATP hydrolysis by using radioactive ATP in place of dUTP in the standard dUTPase reaction mixture (17). All values are reported as mean specific activities (zero order) from different cell batches \pm standard deviations.

\section{RESULTS}

Members of three genera belonging to the class $\mathrm{Mol}$ licutes, each representing a different taxonomic family $(4,5)$, were examined for the ATP-insensitive dUTP-specific hydrolyzing dUTPase of $A$. laidlawii B-PG9 (17) (Table 1) and for other enzyme activities of pyrimidine deoxyribonucleotide metabolism (Table 2). Only cytoplasmic fractions from some Acholeplasma species hydrolyzed dUTP by what we identified as the dUTPase of $A$. laidlawii B-PG9 (Table 1). Although the cytoplasmic fractions from all other members of the Mollicutes tested lacked this activity, some contained a relatively small amount of another type of dUTP- and dCTP-hydrolyzing activity which was completely inhibited by ATP. We also found ATP-inhibitable dUTP- and dCTP-hydrolyzing activity in purified membrane fractions from all members of the Mollicutes examined (Table 3).

The cytoplasmic fractions of all members of the Mollicutes tested had thymidine phosphorylase activity, but none had detectable dUMP phosphatase activity or the specific dCTPhydrolyzing dCTPase activity (Table 2). Except for $A$. florum and $S$. floricola, the cytoplasmic fractions of all members of the Mollicutes tested had $\mathrm{dC}$ deaminase and dCMP deaminase activities (Table 2). The crude lysate fractions (obtained immediately after hypotonic lysis, without further disruption or centrifugation) of all members of the Mollicutes tested had thymidine kinase activity (Table 2).

We also tested purified membrane fractions for dUMP phosphatase activity. We found that membrane fractions from A. laidlawii B-PG9 and A. axanthum $\mathrm{S} 743^{\mathrm{T}}$ had dUMP phosphatase activity $(4.66 \pm 0.21[n=3]$ and $3.30 \pm 0.34[n$ $=3]$ nmol of dUMP hydrolyzed per min per mg of protein, respectively). We found no dUMP phosphatase activity in membrane fractions from $A$. florum $\mathrm{L}^{\mathrm{T}}, S$. floricola $23-6^{\mathrm{T}}$, M. arginini $\mathrm{G} 230^{\mathrm{T}}$, and $M$. hominis ATCC $14027(<0.001$ nmol of dUMP hydrolyzed per min per $\mathrm{mg}$ of protein).

\section{DISCUSSION}

The pattern of our results suggests that it may be possible, after more species are studied, to distinguish some genera within the Mollicutes by the presence or absence of enzymes involved in the metabolism of pyrimidine deoxyribonucleotides. These enzyme activities are (i) the ATP-

TABLE 2. Enzyme activities of pyrimidine deoxyribonucleotide metabolism in cytoplasmic fractions of members of the Mollicutes

\begin{tabular}{|c|c|c|c|c|c|c|c|}
\hline \multirow[b]{2}{*}{ Organism } & \multicolumn{7}{|c|}{ Enzyme activity ${ }^{a}$} \\
\hline & $\begin{array}{l}\text { Thymidine } \\
\text { kinase }^{b}\end{array}$ & $\begin{array}{c}\text { Thymidine } \\
\text { phosphorylase }\end{array}$ & dCTPase & $\begin{array}{c}\mathrm{dC} \\
\text { deaminase }\end{array}$ & $\begin{array}{c}\text { dCMP } \\
\text { deaminase }\end{array}$ & $\begin{array}{c}\text { dUMP } \\
\text { phosphatase }\end{array}$ & dUTPase \\
\hline A. axanthum $\mathrm{S} 743^{\mathrm{T}}$ & $\mathrm{ND}^{d}$ & + & - & + & + & - & + \\
\hline A. granularum BTS-39 & ND & + & - & + & + & - & + \\
\hline A. laidlawii B-PG9 & + & + & - & + & + & - & + \\
\hline A. florum $\mathrm{L}^{\mathrm{T}}$ & + & + & - & - & - & - & - \\
\hline S. foricola $23-6^{\mathrm{T}}$ & + & + & - & - & - & - & _- \\
\hline M. gallisepticum S6 & ND & + & - & + & $(+)$ & - & - \\
\hline M. arginini $\mathrm{G} 230^{\mathrm{T}}$ & + & + & - & + & + & - & - \\
\hline M. hominis ATCC 14027 & + & + & - & + & + & - & - \\
\hline
\end{tabular}

$a+$, Enzyme activity was detected in all cytoplasmic fractions from three or more cells batches; -, enzyme activity was not detected in all cytoplasmic fractions from three or more cell batches: $(+)$, two of three cell batches were positive.

${ }^{b}$ Crude hypotonic lysate was the source of thymidine kinase.

"Data for dUTPase activity were taken from Table 1.

${ }^{d} \mathrm{ND}$, Not done. 
TABLE 3. Nucleotide hydrolyzing activities in membrane fractions of members of the Mollicutes

\begin{tabular}{|c|c|c|c|c|c|}
\hline \multirow[b]{2}{*}{ Organism } & \multicolumn{5}{|c|}{ Substrate $^{a}$} \\
\hline & $\mathrm{dUTP}$ & $\begin{aligned} & \text { dUTP } \\
+ & \text { ATP }^{b}\end{aligned}$ & $\mathrm{dCTP}$ & $\begin{array}{r}\text { dCTP } \\
+\mathrm{ATP}^{b}\end{array}$ & ATP \\
\hline A. laidlawii B-PG9 & $6.3 \pm 2.1$ & $\mathrm{NA}^{c}$ & $7.6 \pm 1.3$ & NA & $10.7 \pm 2.3$ \\
\hline A. axanthum $\mathrm{S} 743^{\mathrm{T}}$ & $5.4 \pm 1.1$ & $\mathrm{NA}$ & $5.8 \pm 1.9$ & NA & $8.4 \pm 2.1$ \\
\hline A. florum L1 ${ }^{\mathrm{T}}$ & $7.6 \pm 2.7$ & NA & $8.4 \pm 1.2$ & NA & $12.5 \pm 2.2$ \\
\hline S. floricola $23-6^{\mathrm{T}}$ & $8.8 \pm 1.2$ & $\mathrm{NA}$ & $9.3 \pm 1.4$ & $\mathrm{NA}$ & $14.1 \pm 1.5$ \\
\hline$M$. arginini $\mathrm{G} 230^{\mathrm{T}}$ & $3.3 \pm 1.5$ & $\mathrm{NA}$ & $4.1 \pm 1.3$ & NA & $5.6 \pm 1.4$ \\
\hline M. hominis ATCC 14027 & $8.2 \pm 1.1$ & NA & $7.6 \pm 2.3$ & NA & $15 \pm 2.3$ \\
\hline
\end{tabular}

${ }^{a}$ Assays for nucleotide hydrolysis were performed by using the reaction conditions described previously for the dUTPase assay (18). Values are means \pm standard deviations from three cell batches (in nanomoles of nucleotide hydrolyzed per minute per milligram of protein).

${ }^{b}$ The concentration of ATP added as a reaction competitor was $5 \mathrm{mM}$.

${ }^{c}$ NA, No activity detected (the minimum detectable amount was 0.001 nmol of nucleotide hydrolyzed per min per mg of protein).

insensitive dUTP-specific hydrolyzing dUTPase (17), (ii) $\mathrm{dC}$ deaminase, (iii) dUMP phosphatase, and (iv) dCMP deaminase. Strains of $S$. floricola and $A$. florum, the only two plant isolates tested, lacked all four enzyme activities. All other Acholeplasma species had all three enzyme activities, whereas all Mycoplasma species had dC and dCMP deaminase activities but no detectable dUTPase or dUMP phosphatase activities. In all members of the Mollicutes tested we detected thymidine kinase and thymidine phosphorylase activities. This confirms the results of previous studies by Hamet et al. (6), who demonstrated thymidine phosphorylase activity in a number of members of the Mollicutes.

Neale et al. $(10,11)$ reported the presence of cytoplasmic dUTPase and dCTPase activities in Mycoplasma mycoides subsp. mycoides. Although we have not examined this organism, none of the six Mycoplasma species which we did examine contained any detectable amounts of these specific enzymatic activities. The differences between our results and those of Neale et al. $(10,11)$ are probably due to intrinsic differences between $M$. mycoides subsp. mycoides and the Mycoplasma species that we studied. However, these differences may also reflect dissimilarities in the stringency of the assays used to detect these enzymes. A problem with measuring dUTPase and dCTPase activities, especially in crude extracts, is that dUTP and dCTP can be hydrolyzed by other enzymes that have a broad substrate specificity $(1,3$, $8,9)$. Such nonspecific enzymes that hydrolyze dUTP and dCTP include nucleoside triphosphatase $(1,9)$, adenosine triphosphatase (8), and alkaline phosphatase (3). Both adenosine triphosphatase $(6,16)$ and an alkaline phosphatase-like activity (12) have been reported in extracts of $A$. laidlawii. Our results (Table 3) demonstrate that a membraneassociated enzyme from a variety of members of the $\mathrm{Mol}$ licutes nonspecifically hydrolyzes both dUTP and dCTP.

We believe that the ATP-inhibitable nonspecific dUTPand dCTP-hydrolytic activity which we found in cytoplasmic fractions was due to membrane contamination. The activities arose from solubilization of the membrane-associated enzymes or from membrane fragments containing these activities that were not sedimented during centrifugal preparation of our cytoplasmic fractions (16).

Our results also demonstrate that the two plant isolates, $A$. florum $\mathrm{L1}^{\mathrm{T}}$ and $S$. floricola $23-6^{\mathrm{T}}$, are identical with respect to the presence or absence of enzyme activities involved with pyrimidine deoxyribonucleotide metabolism. A. florum $\mathrm{L}^{\mathrm{T}}$ has other similarities to $S$. floricola $23-6^{\mathrm{T}}$; they both have no detectable levels of adenosine kinase, adenylosuccinate synthetase, adenylosuccinate lyase, and inosine monophosphate dehydrogenase activities (V. V. Tryon and
J. D. Pollack, unpublished data). In some respects, A florum is unlike other acholeplasmas; it does not synthesize lipids from acetate (15), and an unusually large percentage of its reduced nicotinamide adenine dinucleotide oxidase activity is localized in the cytoplasmic fraction (J. D. Pollack, K. D. Beaman, V. V. Tryon, and J. Robertson, Abstr. 4th Int. Cong. Int. Org. Mycoplasmol., Tokyo, Japan, 1982, F-1, p. 26). We hypothesize that the similarities between $S$. floricola ST $-6^{\mathrm{T}}$ and $A$. florum $\mathrm{L1}^{\mathrm{T}}$ may be related to their associations with plants.

\section{LITERATURE CITED}

1. Agutter, P. S., J. B. Cockrill, J. E. Lavine, B. McCaldin, and R. B. Sim. 1979. Properties of mammalian nuclear-envelope nucleoside triphosphatase. Biochem. J, 181:647-658.

2. Beaman, K. D., and J. D. Pollack. 1981. Adenylate energy charge in Acholeplasma laidlawii. J. Bacteriol. 146:1055-1058.

3. Fishman, W. H. 1974. Perspectives on alkaline phosphatase isoenzymes. Am. J. Med. 56:617-650.

4. Freundt, E. A. 1983. Principles of mycoplasma classification and taxonomy, p. 9-13. In S. Razin and J. G. Tully (ed.), Methods in mycoplasmology, vol. 1. Mycoplasma characterization. Academic Press, Inc., New York.

5. Freundt, E. A., R. F. Whitcomb, M. F. Barile, S. Razin, and J. G. Tully. 1984. Proposal for elevation of the family Acholeplasmataceae to ordinal rank: Acholeplasmatales. Int. J. Syst. Bacteriol. 34:346-349.

6. Hamet, M., C. Bonissol, P. Cartier, A. M. Houllier, and P. Kona. 1980. Enzymatic activities on purine and pyrimidine metabolism by nine mycoplasma species contaminating cell cultures. Clin. Chim. Acta 103:15-22.

7. Jinks, D. C., J. R. Silvius, and R. N. McElhaney. 1978. Physiological role and membrane lipid modulation of the membranebound $\left(\mathrm{Mg}^{2+}, \mathrm{Na}^{+}\right)$-adenosine triphosphatase activity in Acholeplasma laidlawii. J. Bacteriol. 136:1027-1036.

8. Kielley, W. W., H. M. Kalckar, and L. B. Bradley. 1956. The hydrolysis of purine and pyrimidine nucleoside triphosphates by myosin. J. Biol. Chem. 219:95-101.

9. Lewis, M., and S. Weissman. 1965. Properties of a soluble nucleoside triphosphatase activity in mammalian liver. Arch. Biochem. Biophys. 109:490-498.

10. Neale, G. A. M., A. Mitchell, and L. R. Finch. 1983. Pathways of pyrimidine deoxyribonucleotide biosynthesis in Mycoplasma mycoides subsp. mycoides. J. Bacteriol. 154:17-22.

11. Neale, G. A. M., A. Mitchell, and L. R. Finch. 1983. Enzymes of pyrimidine deoxyribonucleotide metabolism in Mycoplasma mycoides subsp. mycoides. J. Bacteriol. 156:1001-1005.

12. Ne'eman, Z., I. Kahane, and S. Razin. 1971. Characterization of the Mycoplasma membrane proteins. II. Solubilization and enzyme activities of Acholeplasma laidlawii membrane proteins. Biochim. Biophys. Acta 249:169-176.

13. Pollack, J. D. 1975. Localization of reduced nicotinamide adenine dinucleotide oxidase activity in Acholeplasma and Mycoplasma. Int. J. Syst. Bacteriol. 25:108-113.

14. Pollack, J. D. 1983. Localization of enzymes in mycoplasmas: 
preparatory steps, p. 327-332. In S. Razin and J. G. Tully (ed.), Methods in mycoplasmology, vol. 1. Mycoplasma characterization. Academic Press, Inc., New York.

15. Pollack, J. D., K. D. Beaman, and J. A. Robertson. 1984. Synthesis of lipids from acetate is not characteristic of Acholeplasma or Ureaplasma species. Int. J. Syst. Bacteriol. 34:124-126.

16. Pollack, J. D., S. Razin, M. E. Pollack, and R. C. Cleverdon.
1965. Fractionation of mycoplasma cells for enzyme localization. Life Sci. 4:973-977.

17. Williams, M. V., and J. D. Pollack. 1984. Purification and characterization of a dUTPase from Acholeplasma laidlawii B-PG9. J. Bacteriol. 159:278-282.

18. Williams, M. V., and J. D. Pollack. 1985. Pyrimidine deoxyribonucleotide metabolism in Acholeplasma laidlawii B-PG9. J. Bacteriol. 161:1029-1033. 